\title{
The Influence of Shopping Orientation on Difficulty Discarding and Disposal Behavior of Fashion Products
}

\author{
Hyun-Hee Park ${ }^{1)}$, Tae-Gue Choo'), and Yang-Suk $\mathrm{Ku}^{2) \dagger}$ \\ ${ }^{1)}$ Dept. of Fashion Design, Kyungpook National University; Sangju, Korea \\ ${ }^{2)}$ Dept. of Clothing \& Textiles, Kyungpook National University, Daegu, Korea
}

\begin{abstract}
Due to the rapid expansion of fashion, consumers easily purchase fashion products, the period of wearing apparel is shortened, and the occurrence of clothes piling up in the closet is increasing. In order to induce and suggest rational consumption and disposal actions, research focused on the factors influencing difficulty discarding and disposal behavior toward a fashion product is needed. Thus, this study considered fashion-shopping orientation as a variable affecting difficulty discarding and disposal behavior toward fashion products. A total of 325 questionnaires were collected, and 11 were discarded due to partial responses or missing data. Finally, a total of 314 survey questionnaires were analyzed. Frequency, exploratory factor, reliability, and multiple regression analyses were employed for data analysis using SPSS 23.0. The study results were as follows. First, hedonic and economic shopping orientation positively affected difficulty discarding a fashion product, whereas rational shopping orientation negatively affected difficulty discarding a fashion product. Second, hedonic, economic, and conspicuous shopping orientation positively affected reuse behavior among disposal behavior toward a fashion product. Third, trend-seeking and convenient shopping orientation positively influenced handover behavior. Fourth, economic and conspicuous shopping orientation positively affected separation discard behavior. The results of this study provide various guidelines for manufacturers and retailers of fashion products.
\end{abstract}

Key words : fashion-shopping orientation, difficulty discarding, compulsive hoarding, disposal behavior

\section{Introduction}

Fast fashion retailers such as H\&M, Zara, and Uniqlo are introducing new lines every 2 3 weeks at very low prices (Bianchi \& Birtwistle, 2012; McAfee et al., 2004). As a result, many consumers expect constant change, so new products have to be available frequently (Bruce \& Daly, 2006). With this trend, the number of fashion items possessed by each consumer has increased dramatically. However, many consumers open closets full of clothes every morning and complain that they have nothing to wear (Woodward, 2007). This means that, although consumers do not use the fashion products anymore, they do not dispose of them and continuously keep or leave them as they are. Consumers are unable to discard such fashion products for diverse reasons. For example, consumers think a product might be used some day although it is not used now, or there is no time to get rid of it, or it contains memories, and so on (Baumgartner, 2012). It is a phenomenon that is contrary to

$\dagger$ Corresponding author; Yang-Suk $\mathrm{Ku}$

Tel. +82-53-950-6223, Fax. +82-53-950-6219

E-mail: yskoo@knu.ac.kr

(C) 2016 (by) the authors. This article is an open access article distributed under the terms and conditions of the Creative Commons Attribution license (http://creativecommons.org/licenses/by/3.0/), which permits unrestricted use, distribution, and reproduction in any medium, provided the original work is properly cited. an efficient, virtuous cycle of clothing. In order to induce and suggest rational consumption and disposal actions, research focused on the factors influencing difficulty discarding and disposal behavior toward a fashion product is needed. However, little empirical research has addressed these relations.

Although consumers' disposal behavior toward a fashion product has been studied in the aspect of environmental consciousness and social responsible consciousness (Jung, 1994; Kang, 1989; Kong, 2012), few studies have approached this problem using consumption-related variables. This study considered fashion-shopping orientation as a variable affecting difficulty discarding and disposal behavior toward fashion products.

In previous studies, fashion-shopping orientation was treated as a significant variable influencing purchase and consumption behavior toward fashion products (Choi, 2015; Ju \& Lee, 2015; Kim \& Rhee, 2004; Lee \& Hwang, 2015; Shim \& Kotsiopulos, 1993). Consumption behavior includes pre- and post-purchase behavior, and disposal behavior is a post-purchase behavior (Jacoby et al., 1977). Although the initial studies about consumption behavior included only purchase and use behavior, recent studies have extended the range of consumption behavior and have included disposal behavior (Bianchi \& Birtwistle, 2010; Jacoby et al., 1977; Winakor, 1969). While understanding acquisition and usage behavior is indeed an important step in understanding overall 
consumption, it is only part of the picture. A thorough investigation and understanding of disposal behavior is paramount to a complete understanding of the entire consumption process. Thus, this study suggests that fashion-shopping orientation will be a useful psychological variable affecting post-purchase behavior, such as difficultly discarding and disposal behavior toward a fashion product as well as purchase behavior.

Identifying the relationship of fashion-shopping orientation, difficulty discarding, and disposal behavior will provide a new opportunity to suggest alternatives for effective clothing management differentiated with previous studies.

\section{Theoretical Background}

\subsection{Fashion-shopping orientation}

The concept of shopping orientation has been defined slightly differently by many scholars. Howell (1979) refers to shopping orientation as a person's shopping lifestyle. This includes consumer's activities, interests, and opinions connected to shopping as a complicated phenomenon related to society, the economy, and a way of spending leisure time. Hawkins et al.(1989) defined shopping orientation as a shopper's style that valued a specific activity. Kim and Rhee (2004) suggested that shopping orientation includes activities, interest, and opinion related to shopping. In particular, fashionshopping orientation is a general purchasing behavior form encompassing psychological and behavioral aspects that appear when purchasing fashion items (Choi, 2015; Kim \& Rhee, 2004; Lee \& $\mathrm{Ku}, 2011$; Park \& Na, 2003). It provided the additional insight for the customer behavior pattern and was treated as an important variable influencing fashion store patronage as well as fashion product and store choice (Moye \& Kincade, 2003).

Most previous studies on fashion-shopping orientation identified factor structure of shopping orientation and typed consumers according to the shopping orientation factors before discovering the characteristics of each type. In addition, they investigated the relationships among shopping orientation and other variables. According to the study of Shim and Kotsiopulos (1993), information source, importance of store attributes, patronage behavior, lifestyle, and demographics differed depending on shopping orientation. Kim and Rhee (1994) insisted that high shopping-involved shoppers highly regarded product attributes, brand, and fashion; recreational shoppers highly regarded brand and fashion; and economic shoppers highly regarded product attributes. Soh and Park (2001) examined consumers' shopping orientations among those with experience buying imported clothing and those with no experience buying imported foreign clothes. Those with experience buying imported clothing enjoyed shopping, pursued famous brands, and showed high ostentation and favorability of foreign brand more than those with no experience. Ju and Lee (2015) explored the influences of shopping orientation and fashion innovativeness of mobile purchasing consumers on perceived mobile benefits. Recreation shopping orientation significantly influenced perceived enjoyment. Fashion-shopping orientation influenced perceived usefulness. Convenience shopping orientation significantly influenced perceived usefulness, perceived ease of use, and perceived enjoyment.

Lately, many studies have been conducted approaching fashionshopping orientation from a global perspective. Choi (2015) investigated the clothing shopping orientation of Chinese female consumers and the characteristics of fashion consumption behaviors according to clothing orientation. As a result, clothing-shopping orientation was verified as an effective segmentation variable for Chinese middle-class female consumers and is expected to have practical implications for differentiated market strategies based on the specific characteristics of each group when Korean apparel companies enter the Chinese women's market. Lee and Hwang (2015) investigated the risk perception of overseas direct purchase felt by consumers depending on their shopping orientation.

\subsection{Difficulty discarding}

Compulsive hoarding can be used as an example of a theory that explains the "save" habit related to clothing. Compulsive hoarding, also known as hoarding disorder, is a pattern of behavior characterized by excessive acquisition and an inability or unwillingness to discard large quantities of objects that cover the living areas of the home and cause significant distress or impairment (Frost \& Gross, 1993; Frost \& Hartl, 1996).

Although the degrees of compulsive hoarding differ, compulsive hoarding does not appear only in certain people. People who make a hobby of collecting things or those who have ever put off tidying their possessions can experience and feel the same way (Jeon \& Lee, 2013).

Compulsive hoarding is known as a symptom that has been more common in foreign countries and which recently emerged into a growing social problem in our country. According to statistics of the world's population, $2 \sim 5 \%$ people have the hoarding disorder (Grisham \& Norberg, 2010).

Salzman (1973) described hoarding as an attempt to exert control over one's environment and to "perfectly" control threat. In addition to these speculations, several case reports of hoarding have described the behavior in more detail (Greenberg, 1987; Leonard et al., 1990). By and large, these accounts linked hoarding to obsessive compulsive disorder. However, little attention was given to defining the phenomenon or developing ways of measuring it. 
Jeon and Lee (2013) focused on identifying the psychological causes leading to compulsive hoarding by normal consumers and investigated sunk cost, anticipated regret, and the effect of personal propensity as the factors influencing compulsive hoarding. First, it was confirmed that sunk cost influenced both compulsive hoarding and anticipated regret. Second, the moderating effect of preference for consistency was significant while possession attachment was not. Third, anticipated regret played a mediating role regarding the effect of sunk cost on compulsive hoarding completely. Thus, this study suggests a comprehensive explanation for the difficulty experienced by consumers in discarding rather than keeping unused products by examining post-acquisition phases that had been neglected in previous studies and clarifying psychological factors leading to compulsive hoarding.

On the other hand, there have been diverse trials to measure this compulsive hoarding. The measure developed by Frost et al. (2004) was used in diverse cultures to diagnose and measure compulsive hoarding (Frost \& Hristova, 2011). It includes three subdimensions: acquiring, clutter, and difficulty discarding.

Difficulty discarding possessions is a core feature of hoarding disorder and is a behavior that has been described in many psychiatric disorders, including obsessive compulsive personality disorder, obsessive compulsive disorder, schizophrenia, anorexia nervosa, dementia, depression, compulsive buying, and mental retardation (Frost et al., 2000; Hwang et al., 1998; Mueller et al., 2007; Pertusa et al., 2010; Steketee et al., 2003). Recent studies have used a difficulty discarding subscale of the SI-R (Saving Inventory-Revised, the most widely used self-report measure of hoarding) to examine the phenomenology of hoarding behaviors in specific samples.

\subsection{Disposal behavior toward a fashion product}

Consumer behavior research so far has been focused on purchasing behavior; research on retention and disposal behaviors is lacking. Disposal behavior emerged as an important aspect of consumption behavior in studies by Jacoby (1976) and Nicosia and Mayer (1976). Nicosia and Mayer (1976) suggested that consumption activities can be defined as storing, using, maintaining, repairing, and disposing of the purchased product. Burke et al. (1978) defined disposal behavior as the activities households apply to products when the products lose the function of their original purpose. Winakor (1969) suggested that disposal behavior is the last step of clothing consumption and that the usage rate and period before disposal are influenced by diverse personal traits and external stimuli such as consumers' age, activities, and goals; the value, quality, and quantity of their clothing; and fashion.

Looking at the studies on type and influencing factors of dis- posal behavior, Harrel and McConocha (1992) classified disposal behavior as altruistic behavior, such as giving away and donation, and non-altruistic behavior, such as keeping and throwing away. In the study by Chang and Park (1997), socially responsible disposal behavior was divided into economic disposal and altruistic disposal, and then the relationship between the socially responsible clothing consumption attitude and demographic variables was investigated. The analysis showed that consumers with relatively lower education normally displayed economical dispositions while consumers with higher education levels displayed altruistic dispositions. Additionally, elder and married consumers had greater tendency to display altruistic dispositions. Morgan and Birtwistle (2009) classified disposal behavior in the following categories: selling via online and offline stores, giving to charity shops, putting in recycling bins, giving to family members or friends, and reusing in the home; giving to charity shops was the most common method of clothing disposal. Kim and Cho (2000) classified the clothing disposal behavior of unmarried woman workers into altruistic and economic recycling disposal behavior. Altruistic recycling disposal behavior was higher in the office-going and leaving clothing group than in the group of people with separate uniforms as working dress; it also was higher in the group of those experienced in environmental education and in the group of those of high subjective social strata. In the study by Kong (2012), clothing disposal behavior was divided into reuse disposal (barter with those around me, donate to relatives/acquaintances, garage sale, donate to school or religious group) and nonuse disposal (putting in clothing bin, keeping, throwing away with garbage), and the study confirmed that there were negative relations between socially responsible consciousness and nonuse disposal behavior. Kwon (2014) insisted that clothing disposal was directly influenced by purchasing new clothing, and clothing disposal intention was enhanced by eliciting the emotion of boredom with clothing in possession. VeVerka (1974) suggested that consumers consider the disposal of clothing in their possession when the current utilization value is lower than the current cost or when the holding cost surpasses the clothing disposal cost. Domina and Koch (1999) said that consumers tend to dispose the clothes for which they paid a high price or with high value through giving, donation, and resale.

Looking at these previous studies, fashion-shopping orientation is influenced by lifestyle and value and is fluid depending on social change. It is treated as the major factor of fashion product consumption and purchasing behavior since it can be a market segmentation criterion as the important variable in fashion product and store choice (Choi, 2015). However, in prior studies, shopping orientation was utilized as a major variable to predict consumption attitude and purchasing behavior toward fashion products, and few 
studies have examined the relation with post-purchase behavior such as difficulty discarding and disposal behavior. In addition, disposal behavior was divided into slightly different factors according to researchers' perspectives, and diverse factors influencing these disposal behaviors have been studied. However, the relation between shopping orientation and disposal behavior has not been studied. Thus, this study extends previous studies related to shopping orientation and examines the influence of shopping orientation on difficulty discarding and disposal behavior. The results of this study will provide practical implications related to efficient clothing management.

Through review of previous research, the following research questions were established.

RQ 1: Identify the factor structure of fashion-shopping orientation.

RQ 2: Identify the factor structure of disposal behavior toward fashion products.

RQ 3: Investigate the influence of fashion-shopping orientation on difficulty discarding.

RQ 4: Investigate the influence of fashion-shopping orientation on disposal behavior.

\section{Method}

\subsection{Data collection and analysis}

A survey method was used to investigate the influence of shopping orientation and difficulty discarding a fashion product. To reduce non-responses, the researchers fully explained to the respondents about the purpose of study and the way of filling in the questionnaire. The survey was conducted from March 2 16, 2016. Purposive sampling provided a sample representative of the population and targeted group (Teddlie \& Yu, 2007). In this study, we conducted the survey for university students. Because university students are the main target of fast fashion, and their consumption and disposal behavior of fashion products has changed a lot compared with past university students. Data was collected, via the survey method, from university students in Daegu and Gyeonsangbukdo, South Korea.

A total of 350 questionnaires were distributed. Finally, 314 questionnaires were used for analysis after excluding incomplete responses.

The sample characteristics were as follows. Of the respondents, $43.8 \%$ were male, and $56.2 \%$ were female while $36.6 \%$ were juniors, $32.5 \%$ were sophomores, $29.3 \%$ were seniors, and $1.6 \%$ were freshman. Of these respondents, $36.3 \%$ earned $\$ 300$ to $\$ 400$ for their monthly pocket money, $25.2 \%$ earned $\$ 200$ to $\$ 300$, and
$15.3 \%$ earned $\$ 400$ to $\$ 500$.

Frequency, factor, reliability, and multiple regression analyses were employed for the analysis of data using SPSS 23.0.

\subsection{Measures}

Fashion-shopping orientation was measured using 35 items adapted from previous studies (Ji, 2013; Kim \& Ha, 2011; Kim et al., 2009; Lee, 2010; Park \& Kim, 2008). Difficulty discarding fashion product was measured using 6 items adapted from prior studies (Frost et al., 2004; Hyeon, 2014; Jeon \& Lee, 2013). Disposal behavior toward fashion products was measured using 8 items adapted from previous studies (Kong, 2012; Lee \& Choi, 2002). All variables were measured using a seven-point Likert-type scale ranging from "strongly disagree" (1) to "strongly agree" (7).

\section{Results \& Discussion}

\subsection{Reliability and validity test}

Coefficient $\alpha$ scores were calculated for each construct to show internal consistency. The results are revealed on the right sides of Tables 1 and 2. The Cronbach's $\alpha$ values ranged from 0.643 to 0.932 . The Cronbach's $\alpha$ values above 0.60 are considered acceptable (Nunnally, 1978). All values showed that internal consistency reliability of each construct was adequate. Exploratory factor analysis with principal component analysis and varimax rotation was used to check the convergent and discriminant validity of the scales item. The number of factors was decided by the criteria of eigen value above 1.0 and factor loading above 0.4. All factor loading scores were greater than 0.40 , indicating a highly stable loading structure.

As shown in Table 1, fashion-shopping orientation had an eightfactor solution, altogether explaining $69.41 \%$ of total variance. These eight factors were named based on the items that loaded the highest for each factor. Factor 1 had five statements and accounted for $23.567 \%$ of the common variance. Since all the statements loaded in this factor measured a motive to be able to enjoy shopping, this factor was conceptually labeled as the hedonic shopping orientation. Factor 2 had six statements and accounted for $13.070 \%$ of common variance. This factor was labeled as the economic shopping orientation since all statements were characterized by the search for sales, cheap prices, and discount coupons, and so on, during fashion-shopping. Factor 3 had four statements and accounted for $7.717 \%$ of common variance. This factor was labeled as the conspicuous shopping orientation because all statements were related to the fame of brands, designers, and companies when buying fashion products. Factor 4 had four statements and accounted for $6.118 \%$ of common variance. This factor was 
Table 1. Exploratory factor analysis and reliability analysis of fashion product shopping orientation

\begin{tabular}{|c|c|c|c|c|c|}
\hline Construct & Factor & Items & $\begin{array}{l}\text { Factor } \\
\text { loading }\end{array}$ & $\begin{array}{c}\text { Eigen value } \\
\text { (variance) }\end{array}$ & $\begin{array}{c}\text { Cronbach's } \\
\alpha\end{array}$ \\
\hline \multirow{8}{*}{$\begin{array}{l}\text { Fashion } \\
\text { shopping } \\
\text { orientation }\end{array}$} & Hedonic & $\begin{array}{l}\text { I feel better if I am shopping when I am nervous and have anxiety. } \\
\text { Shopping is the best way to spend my spare time. } \\
\text { I shop to get rid of daily life stress. } \\
\text { Buying clothes itself gives me pleasure. } \\
\text { I like shopping. }\end{array}$ & $\begin{array}{l}.867 \\
.861 \\
.833 \\
.813 \\
.785\end{array}$ & $\begin{array}{c}8.249 \\
(23.567)\end{array}$ & .932 \\
\hline & Economic & $\begin{array}{l}\text { I purchase the product on sale. } \\
\text { I mainly buy the sale product or planning product. } \\
\text { First, I look at the sale products, and then, I look at the other items. } \\
\text { I visit off-price stores or use discount coupons. } \\
\text { I invest a lot of time to buy cheap products. } \\
\text { I have a tendency to purchase comparatively low-priced products. }\end{array}$ & $\begin{array}{l}.815 \\
.813 \\
.758 \\
.705 \\
.685 \\
.457\end{array}$ & $\begin{array}{c}4.575 \\
(13.070)\end{array}$ & .841 \\
\hline & Conspicuous & $\begin{array}{l}\text { I tend to purchase the fashion products of famous brands and designers. } \\
\text { Although a fashion product is somewhat expensive, I will buy it because it was } \\
\text { manufactured by a famous company. } \\
\text { I tend to purchase fashion products that are purchased by people with more money } \\
\text { than me. } \\
\text { I mainly buy the product that appears to have better quality. }\end{array}$ & $\begin{array}{l}.857 \\
.832 \\
.824 \\
.673\end{array}$ & $\begin{array}{c}2.701 \\
(7.717)\end{array}$ & .850 \\
\hline & Trend-seeking & $\begin{array}{l}\text { I select fashionable designs after looking at up-to-date fashion carefully. } \\
\text { I tend to buy trending fashion items. } \\
\text { I buy fashionable products after searching fashion trends and information through } \\
\text { the internet. } \\
\text { I have a lot of interest in new fashion trends. }\end{array}$ & $\begin{array}{l}.850 \\
.820 \\
.812 \\
.688\end{array}$ & $\begin{array}{c}2.141 \\
(6.118)\end{array}$ & .885 \\
\hline & Rational & $\begin{array}{l}\text { I check the clothes that I have before buying new clothes. } \\
\text { To figure out the price in advance is helpful to buy fashion products later. } \\
\text { I tend to budget in advance to buy fashion products. } \\
\text { I investigate the style and price and compare at several fashion stores. } \\
\text { I invest a lot of time to buy good-quality and low-price fashion products. }\end{array}$ & $\begin{array}{l}.714 \\
.707 \\
.702 \\
.637 \\
.609\end{array}$ & $\begin{array}{c}1.989 \\
(5.684)\end{array}$ & .786 \\
\hline & Convenient & $\begin{array}{l}\text { I use the most convenient store when I buy clothes. } \\
\text { I mainly utilize the one-stop shopping store, which has diverse items and brands. } \\
\text { I shop in a place conveniently situated for timesaving. } \\
\text { I enjoy shopping at a store that has a lot of convenient facilities and relaxing spaces. }\end{array}$ & $\begin{array}{l}.807 \\
.788 \\
.754 \\
.674\end{array}$ & $\begin{array}{c}1.695 \\
(4.841)\end{array}$ & .801 \\
\hline & $\begin{array}{c}\text { Brand/store } \\
\text { loyalty }\end{array}$ & $\begin{array}{l}\text { I buy the brand continuously if I like a brand. } \\
\text { I have a brand that I repeatedly purchase. } \\
\text { If I discover a store that I like, I continuously use that store. } \\
\text { When I buy clothes, I mainly use a regular store. }\end{array}$ & $\begin{array}{l}.873 \\
.811 \\
.728 \\
.672\end{array}$ & $\begin{array}{c}1.510 \\
(4.314)\end{array}$ & .839 \\
\hline & $\begin{array}{l}\text { Internet } \\
\text { pursuit }\end{array}$ & $\begin{array}{l}\text { Internet shopping is good because I can buy clothes at any time. } \\
\text { When I buy fashion products, I prefer internet shopping to crowded offline stores. } \\
\text { When I shop on the internet, I like sites where searching is convenient. }\end{array}$ & $\begin{array}{l}.868 \\
.848 \\
.700\end{array}$ & $\begin{array}{c}1.435 \\
(4.099)\end{array}$ & .808 \\
\hline
\end{tabular}

labeled as the trend-seeking shopping orientation since all statements were characterized by the purchase of up-to-date, new, fashionable fashion products. Factor 5 had five statements and accounted for $5.684 \%$ of common variance. This factor described a reasonable and intelligent shopping orientation and was labeled as the rational shopping orientation. Factor 6 had four statements and accounted for $4.841 \%$ of common variance. This factor showed high importance of quick and easy shopping within a limited time and was therefore labeled as the convenient shopping orientation. Factor 7 had four statements and accounted for $4.314 \%$ of common variance. This factor was labeled as the brand and store loyalty ori- entation since it was characterized by continuous purchases of a brand and visits to a store. Factor 8 had three statements and accounted for $4.099 \%$ of common variance. This factor was labeled as the internet pursuit orientation because it was characterized by the preference for internet shopping.

As shown in Table 2, difficulty discarding had a one-factor solution, explaining $69.051 \%$ of total variance. Disposal behavior had a three-factor solution, altogether explaining $67.417 \%$ of total variance. These three factors were named based on the items that loaded the highest for each factor. Factor 1 had three statements and accounted for $40.903 \%$ of the common variance. This factor 
Table 2. Exploratory factor analysis and reliability analysis of difficulty discarding and disposal behavior

\begin{tabular}{|c|c|c|c|c|c|}
\hline Construct & Factor & Items & $\begin{array}{l}\text { Factor } \\
\text { loading }\end{array}$ & $\begin{array}{l}\text { Eigen value } \\
\text { (variance) }\end{array}$ & $\begin{array}{c}\text { Cronbach's } \\
\alpha\end{array}$ \\
\hline Difficulty & discarding & $\begin{array}{l}\text { The task of throwing fashion products away is distressing. } \\
\text { It is not easy to throw away fashion products I do not use anymore. } \\
\text { I have a tendency to save fashion products although I know I may never use them. } \\
\text { It is difficult to throw away the fashion products that I have. } \\
\text { I avoid trying to discard the fashion products that I have because it is too stressful. } \\
\text { I often make a decision about making a space to keep the fashion products that I do } \\
\text { not use. }\end{array}$ & $\begin{array}{l}.887 \\
.873 \\
.851 \\
.817 \\
.813 \\
.737\end{array}$ & $\begin{array}{c}4.143 \\
(69.051)\end{array}$ & .910 \\
\hline \multirow{3}{*}{$\begin{array}{l}\text { Disposal } \\
\text { behavior }\end{array}$} & Reuse & $\begin{array}{l}\text { Wear again after fixing the size and design, etc. } \\
\text { Use it after reforming for other purposes (working clothes, children's clothes, etc.). } \\
\text { Sell it to a secondhand dealer or on the internet. }\end{array}$ & $\begin{array}{l}.810 \\
.771 \\
.667\end{array}$ & $\begin{array}{c}3.272 \\
(40.903)\end{array}$ & .704 \\
\hline & $\begin{array}{l}\text { Hand } \\
\text { over }\end{array}$ & $\begin{array}{l}\text { Give it to acquaintances such as relatives or neighbors. } \\
\text { Change garments or barter with surrounding people. } \\
\text { Donate to religious organizations, schools, and charities (orphanages, nurseries). }\end{array}$ & $\begin{array}{l}.843 \\
.683 \\
.588\end{array}$ & $\begin{array}{c}1.078 \\
(13.474)\end{array}$ & .643 \\
\hline & $\begin{array}{l}\text { Separation } \\
\text { discard }\end{array}$ & $\begin{array}{l}\text { Discard after separating the things that can be reused such as pure wool. } \\
\text { Discard after separating the useful components such as buttons and zippers, etc. }\end{array}$ & $\begin{array}{l}.863 \\
.783\end{array}$ & $\begin{array}{c}1.043 \\
(13.040)\end{array}$ & .695 \\
\hline
\end{tabular}

was characterized by the reforming, reselling, and fixing, among other things, when getting rid of clothes and was labeled as "reuse." Factor 2 had three statements and accounted for $13.474 \%$ of the common variance. This factor was labeled as "hand over" since it was related to giving clothes to other people and organizations. Factor 3 had two statements and accounted for $13.040 \%$ of the common variance. This factor was labeled as "separation discarding" since it described the discarding of clothes after separating useful things.

Pearson correlation analysis was conducted to analyze the correlations between factors. It was judged that the factors had discriminant validity since the correlation coefficients of all factors were below 0.5 (Chaiy, 2007).

\subsection{Research question test}

The VIF(Variance Inflation Factor) measures the impact of collinearity among the variables in a regression model. Values of VIF that exceed 10 are often regarded as indicating multicollinearity. In addition, VIF is just the reciprocal of tolerance statistics. Some suggest that a tolerance value less than 0.1 should be investigated further. If a low tolerance value is accompanied by large standard errors and non-significance, multicollinearity may be an issue (Koo, 2013). As shown in Table 4 7, VIF is lower than 10 and tolerance is larger than 0.1 . Thus, it was judged that the multicollinearity problem could be ignored.

After confirming the reliability and validity of each variable, multiple regression analysis was conducted to verify the influence

Table 3. Correlation analysis

\begin{tabular}{|c|c|c|c|c|c|c|c|c|c|c|c|c|}
\hline & (1) & (2) & (3) & (4) & (5) & (6) & (7) & (8) & (9) & (10) & (11) & $(12)$ \\
\hline Rational (1) & 1 & & & & & & & & & & & \\
\hline Conspicuous (2) & .093 & 1 & & & & & & & & & & \\
\hline Hedonic (3) & $.398^{* *}$ & $.309^{* *}$ & 1 & & & & & & & & & \\
\hline Brand/store loyal (4) & $.258^{* *}$ & $.244^{* *}$ & $.426^{* *}$ & 1 & & & & & & & & \\
\hline Convenient (5) & $.202^{* *}$ & .059 & .050 & $.256^{* *}$ & 1 & & & & & & & \\
\hline Internet pursuit (6) & $.325^{* *}$ & -.024 & $.164^{* *}$ & .089 & $.265^{* *}$ & 1 & & & & & & \\
\hline Economic (7) & $.420^{* *}$ & -.092 & $.113^{*}$ & .103 & $.320^{* *}$ & $.343^{* *}$ & 1 & & & & & \\
\hline Trend-seeking (8) & $.347^{* *}$ & $.290^{* *}$ & $.484^{* *}$ & $.336^{* *}$ & $.213^{* *}$ & $.243^{* *}$ & $.187^{* *}$ & 1 & & & & \\
\hline Difficulty discarding (9) & .060 & $.117^{*}$ & $.264^{* *}$ & $.117^{*}$ & .067 & .085 & $.186^{* *}$ & $.225^{* *}$ & 1 & & & \\
\hline Reuse (10) & .103 & $.205^{* *}$ & $.262^{* *}$ & $.128^{*}$ & .064 & .104 & $.167^{* *}$ & $.231^{* *}$ & $.289^{* *}$ & 1 & & \\
\hline Hand over (11) & .072 & $.160^{* *}$ & $.165^{* *}$ & .064 & $.154^{* *}$ & .021 & .095 & $.238^{* *}$ & .086 & $.450^{* *}$ & 1 & \\
\hline Separation discard (12) & .078 & $.155^{* *}$ & .101 & -.003 & .039 & .077 & $.127^{*}$ & .051 & $.128^{*}$ & $.380^{* *}$ & $.375^{* *}$ & 1 \\
\hline
\end{tabular}

${ }^{*} p<.05, \quad{ }^{* *} p<.01$ 
Table 4. Influence of shopping orientation on difficulty discarding

\begin{tabular}{|c|c|c|c|c|c|c|c|}
\hline Dependent variable & $\begin{array}{l}\text { Independent variable } \\
\text { (shopping orientation) }\end{array}$ & $\beta$ & $t$ & $R^{2}$ & $F$ & Tolerance & VIF \\
\hline \multirow{8}{*}{ Difficulty discarding } & Hedonic & .252 & $3.628^{* * *}$ & \multirow{8}{*}{.126} & \multirow{8}{*}{$5.446^{* * *}$} & .607 & 1.646 \\
\hline & Economic & .209 & $3.278^{* *}$ & & & .717 & 1.394 \\
\hline & Conspicuous & .048 & .817 & & & .839 & 1.193 \\
\hline & Trend-seeking & .113 & 1.718 & & & .673 & 1.486 \\
\hline & Rational & -.166 & $-2.513^{*}$ & & & .664 & 1.507 \\
\hline & Convenient & -.003 & -.050 & & & .798 & 1.253 \\
\hline & Brand/store loyalty & -.013 & -.209 & & & .739 & 1.353 \\
\hline & Internet pursuit & .003 & .045 & & & .801 & 1.249 \\
\hline
\end{tabular}

${ }^{*} p<.05,{ }^{* *} p<.01,{ }^{* * *} p<.001$

of fashion-shopping orientation on difficulty discarding and disposal behavior toward fashion products. The results of multiregression test are revealed in Tables 4 7.

First, the influence of fashion-shopping orientation on difficulty discarding was tested; the F-value was 5.466, and the influence was significant at the level of 0.01 . As for the analysis result of subdimensions, hedonic shopping orientation $(\beta=.252, p<.001)$ and economic shopping orientation $(\beta=.209, p<.01)$ positively affected difficulty discarding, and rational shopping orientation $(\beta=-.166, p$ $<.05)$ negatively impacted difficulty discarding. It was revealed that other shopping orientation factors did not affect difficulty discarding (refer to Table 4).

Next, the influence of fashion-shopping orientation on disposal behavior toward fashion products was tested.

First, the influence of fashion-shopping orientation on reuse behavior among disposal behavior was tested. As a result, the $F$ -

Table 5. Influence of shopping orientation on reuse behavior

\begin{tabular}{|c|c|c|c|c|c|c|c|}
\hline $\begin{array}{l}\text { Dependent } \\
\text { variable }\end{array}$ & $\begin{array}{l}\text { Independent variable } \\
\text { (shopping orientation) }\end{array}$ & $\beta$ & $t$ & $R^{2}$ & $F$ & Tolerance & VIF \\
\hline \multirow{8}{*}{ Reuse } & Hedonic & .188 & $2.702^{* *}$ & \multirow{8}{*}{.123} & \multirow{8}{*}{$5.189^{* * *}$} & .607 & 1.646 \\
\hline & Economic & .179 & $2.795^{* *}$ & & & .717 & 1.394 \\
\hline & Conspicuous & .149 & $2.506^{*}$ & & & .839 & 1.193 \\
\hline & Trend-seeking & .098 & 1.480 & & & .673 & 1.486 \\
\hline & Rational & -.098 & -1.467 & & & .664 & 1.507 \\
\hline & Convenient & -.017 & -.277 & & & .798 & 1.253 \\
\hline & Brand/store loyalty & -.013 & -.205 & & & .739 & 1.353 \\
\hline & Internet pursuit & .029 & .479 & & & .801 & 1.249 \\
\hline
\end{tabular}

${ }^{*} p<.05, \quad{ }^{* *} p<.01, \quad{ }^{* * *} p<.001$

Table 6. Influence of shopping orientation on hand-over behavior

\begin{tabular}{|c|c|c|c|c|c|c|c|}
\hline $\begin{array}{l}\text { Dependent } \\
\text { variable }\end{array}$ & $\begin{array}{l}\text { Independent variable } \\
\text { (shopping orientation) }\end{array}$ & $\beta$ & $t$ & $R^{2}$ & $F$ & Tolerance & VIF \\
\hline \multirow{8}{*}{ Hand over } & Hedonic & .100 & 1.411 & \multirow{8}{*}{.092} & \multirow{8}{*}{$3.772^{* * *}$} & .607 & 1.646 \\
\hline & Economic & .071 & 1.092 & & & .717 & 1.394 \\
\hline & Conspicuous & .098 & 1.630 & & & .839 & 1.193 \\
\hline & Trend-seeking & .184 & $2.723^{* *}$ & & & .673 & 1.486 \\
\hline & Rational & -.052 & -.772 & & & .664 & 1.507 \\
\hline & Convenient & .133 & $2.142^{*}$ & & & .798 & 1.253 \\
\hline & Brand/store loyalty & -.085 & -1.326 & & & .739 & 1.353 \\
\hline & Internet pursuit & -.072 & -1.166 & & & .801 & 1.249 \\
\hline
\end{tabular}

${ }^{*} p<.05,{ }^{* *} p<.01, \quad{ }^{* * *} p<.001$ 
Table 7. Influence of shopping orientation on separation discard behavior

\begin{tabular}{|c|c|c|c|c|c|c|c|}
\hline $\begin{array}{l}\text { Dependent } \\
\text { variable }\end{array}$ & $\begin{array}{l}\text { Independent variable } \\
\text { (shopping orientation) }\end{array}$ & $\beta$ & $t$ & $R^{2}$ & $F$ & Tolerance & VIF \\
\hline \multirow{8}{*}{ Separation discard } & Hedonic & .085 & 1.179 & \multirow{8}{*}{.054} & \multirow{8}{*}{$2.130^{*}$} & .607 & 1.646 \\
\hline & Economic & .139 & $2.082^{*}$ & & & .717 & 1.394 \\
\hline & Conspicuous & .177 & $2.876^{* *}$ & & & .839 & 1.193 \\
\hline & Trend-seeking & -.048 & -.703 & & & .673 & 1.486 \\
\hline & Rational & -.006 & -.084 & & & .664 & 1.507 \\
\hline & Convenient & .002 & .031 & & & .798 & 1.253 \\
\hline & Brand/store loyalty & -.083 & -1.261 & & & .739 & 1.353 \\
\hline & Internet pursuit & .040 & .642 & & & .801 & 1.249 \\
\hline
\end{tabular}

$p<.05, \quad p<.01$

value was 5.189, and the influence was significant at the level of .001. Specifically, hedonic shopping orientation $(\beta=.188, p<.01)$, economic shopping orientation $(\beta=.179, p<.01)$, and conspicuous shopping orientation $(\beta=.149, p<.05)$ positively affected reuse disposal behavior (refer to Table 5).

Second, the influence of fashion-shopping orientation on handover behavior among disposal behavior was tested. As a result, the $F$-value was 3.772, and the influence was significant at the level of .001 . Specifically, trend seeking shopping orientation $(\beta=.184, p<$ $.01)$ and convenient shopping orientation $(\beta=.133, p<.05)$ positively affected hand-over disposal behavior (refer to Table 6).

Third, the influence of fashion-shopping orientation on separation discard among disposal behavior was tested. As a result, the $F$ value was 2.130 , and the influence was significant at the level of .05. Specifically, economic shopping orientation $(\beta=.139, p<.05)$, and conspicuous shopping orientation $(\beta=.177, p<.01)$ positively affected separation discard disposal behavior (refer to Table 7).

\section{Conclusion}

Until now, fashion-shopping orientation was dealt with in the context of purchase of fashion products. However, today's fashion environment is changing fast. Due to the rapid expansion of fashion, consumers easily purchase fashion products, the period of wearing apparel is shortened, and the occurrence of clothes piling up in the closet is increasing. Thus, it is predicted that fashionshopping orientation will influence post-purchase consumption behavior, disposal behavior, and purchase behavior of fashion products. Thus, this study investigated the influence of shopping orientation on difficulty discarding and disposal behavior.

The results and implications are as follows.

First, as a result of the influence of shopping orientation on difficulty discarding, the stronger the hedonic and economic shopping orientation were, the higher the difficulty discarding fashion prod- ucts was while, the stronger rational shopping orientation was, the lower the difficulty discarding of fashion product was.

The consumers with hedonic shopping orientation utilize shopping as a tool to refresh their mood (Kim \& Rhee, 2000), have high impulse buying tendency, and strongly respond to fashion shows and displays (Kang, 1999). Thus, it is judged that, due to sunk cost effect, consumers are able to hold on to fashion products purchased through impulse buying although they do not use them anymore.

In addition, it is judged that consumers with high economic shopping orientation focus on economic aspects and are accustomed to economizing, and they have a high degree of difficulty discarding. At the same time, it is judged that the consumers with strong rational shopping orientation will purchase necessary fashion products and clean up unnecessary fashion products since make planned purchases.

Second, as a result of testing the influence of fashion-shopping orientation on disposal behavior, it appeared that hedonic, economic, and conspicuous shopping orientations positively affected reuse behavior.

It is judged that consumers with strong hedonic shopping orientation receive fun and pleasure through reuse behavior such as reforming, fixing, and so on, since hedonic shopping orientation means fun, excitement, and satisfaction gained in the process of fashion product consumption (Hirschman \& Holbrook, 1982). Consumers with high conspicuous shopping orientation chase fashion and have a strong propensity to express their differentiated beauty and personality through their own symbolic product or brand. Thus, when they dispose of their fashion products, they are interested in reform in various types and usage of fashion products. Economic shopping orientation is a concept that particularly highlights the cost aspect. The stronger consumers' economic shopping orientation was, the more actively they reused fashion products, especially selling on the internet and to secondhand shops.

Third, as a result of testing the influence of fashion-shopping ori- 
entation on hand-over behavior among disposal behavior, it appeared that convenient and fashion-shopping orientations positively affected hand-over behavior. Convenient shopping orientation is an inclination to pursue more comfortable and efficient shopping. Thus, it is judged that consumers with strong convenient shopping orientation believe hand-over behavior, such as giving to relatives and acquaintances or donating to charity, is more convenient and efficient than making an effort to reuse and discard. Trend-seeking fashion orientation is a tendency to purchase fashionable products. It is judged that consumers with trend-seeking shopping orientation are interested in the latest new fashion products and do not want to make efforts for reuse or separation discard. Therefore, they prefer to simply hand over to others.

Fourth, as a result of testing the influence of fashion-shopping orientation on separation discard among disposal behavior, it appeared that economic and conspicuous shopping orientations positively affected separation discard. It is judged that consumers with strong economic shopping orientation prefer to separation discard among disposal behaviors since they view value for cost as important. They throw away the fashion products after separating buttons, zippers, pure wool, and so no, from them. It is judged that consumers with strong conspicuous shopping orientation prefer to separation discard - that is, to discard fashion products after separating important parts since they pursue the symbolic value of fashion products.

The significance and implications of this study are as follows.

First, this study was the first study confirming that fashion-shopping orientation was a significant variable influencing difficulty discarding and disposal behavior toward fashion products as well as variables influencing purchase behavior.

Second, shopping orientation can be used as the classification variable to establish efficient a clothing management strategy since it affects difficulty discarding. It is possible to actually understand clothing resources through a process of organizing our closet. Sometimes, we find valuable fashion items that we did not notice by arranging fashion products. It helps us do efficient clothing management and keep a pleasant clothing management environment. In this study, the result showed that the consumers with strong hedonic and economic shopping orientation had higher degrees of difficulty discarding unused fashion products. Thus, these consumers need to be educated about the benefits which could be gained through clothing arranging processes and/or clothing amount fit to personal clothing space to them. Actual condition survey of clothing management for the consumers with strong rational shopping orientation would provide useful information of clothing management, since rational shopping orientation negatively affects difficulty discarding.
Third, diverse methods of clothing management according to the consumers' shopping orientation could be suggested. Educators and retailers can leverage the findings of this study in suggesting to young consumers for the disposition method of their unused products. That is, it will be helpful to practical clothing management to educate diverse reuse methods to the consumers with strong hedonic, economic, and conspicuous shopping orientation. For example, how to transform adult clothing into children's clothes or aprons etc., how to transform by adding a bit of detail on the clothing to match the fashion trends, and alteration of use through the innovative design variation would be suggested. In particular, it will be effective to suggest the way to reuse separate-discarded clothing resources to the consumers with economic and conspicuous shopping orientation. It will be helpful to provide the lists of clothing donation organizations and stores since recommending hand-over to the consumers with strong trend-seeking and convenient shopping orientation was more effective than reuse and separation-discard.

This study intended to determine the influence of fashion-shopping orientation on difficulty discarding and disposal behavior. However, study contents and study method had limitations for generalization of study results. For example, they may include methodological restrictions, the problem of purification of measurement variables, and lack of analysis method rigidity.

In the future, the study of the specific way to induce a reasonable fashion product storage and disposal behavior should be performed by extracting a study model for the relationship between storage and disposal behavior toward fashion products and conducting strict causal analysis including other psychological variables besides fashion-shopping orientation such as materialism and social responsible clothing consumption attitude.

\section{References}

Baumgartner, J. (2012). You are what you wear: What your clothes reveal about you. Philadelphia, PA: Da Capo Press.

Bianchi, C., \& Birtwistle, G. (2010). Sell, give away, or donate: An exploratory study of fashion clothing disposal behavior in two countries. International Review of Retail, Distribution and Consumer Research, 20(3), 353-368. doi:10.1080/09593969.2010.491213

Bianchi, C., \& Birtwistle, G. (2012). Consumer clothing disposal behavior: A comparative study. International Journal of Consumer Studies, 36(3), 335-341. doi:10.1111/j.1470-6431.2011.01011.x

Bruce, M., \& Daly, L. (2006). Buyer behavior for fast fashion. Journal of Fashion Marketing and Management, 10(3), 329-344. doi:10.1108/ 13612020610679303

Burke, M. W., Conn, D., \& Lutz, R. J. (1978). Using psychographic variables to investigate product disposion behavior. Proceedings of the AMA Educators Conference (pp. 321-326), Jain S.C.(ed.). Chicago, IL: American Marketing Association. 
Chaiy, S. (2007). Marketing research. Seoul: Bnmbook.

Chang, G. H., \& Park, J. O. (1997). The effects of the socially responsible clothing consumption attitude on the clothing disposition behavior. Journal of the Korean Society of Clothing and Textiles, 21(4), 795-805.

Choi, M. Y. (2015). The characteristics of fashion consumption behaviors based on Chinese female consumers' clothing shopping orientation. Journal of the Korean Society of Fashion Design, 15(2), 109-127.

Domina, T., \& Koch, K. (1999). Consumer reuse and recycling of post consumer textile waste. Journal of Fashion Marketing and Management, 3(4), 346-359. doi:10.1108/eb022571

Koo, D. M. (2013). Research methodology. Paju: Hakhyunsa.

Frost, R. O., \& Gross, R. C. (1993). The hoarding of possessions. Behaviour Research and Therapy, 31(4), 367-381. doi:10.1016/ 0005-7967(93)90094-B

Frost, R. O., \& Hartl, T. L. (1996). A cognitive-behavioral model of compulsive hoarding. Behavior Research and Therapy, 34(4), 341-350. doi:10.1016/0005-7967(95)00071-2

Frost, R. O., \& Hristova, V. (2011). Assessment of hoarding. Journal of Clinical Psychology, 67(5), 456-466. doi:10.1002/jclp.20790

Frost, R. O., Steketee, G., \& Grisham, J. (2004). Measurement of compulsive hoarding: Saving inventory-revised. Behaviour Research and Therapy, 42(10), 1163-1182. doi:10.1016/j.brat.2003.07.006

Frost, R. O., Steketee, G., Williams, L. F., \& Warren, R. (2000). Mood, personality disorder symptoms and disability in obsessive compulsive hoarders: A comparison with clinical and nonclinical controls. Behavior Research and Therapy, 38(11), 1071-1081. doi:10.1016/S0005-7967(99)00137-0

Greenberg, D. (1987). Compulsive hoarding. American Journal of Psychotherapy, 41(3), 409-416.

Grisham, J. R., \& Norberg, M. M. (2010). Compulsive hoarding: Current controversies and new directions. Dialogues in Clinical Neuroscience, 12(2), 233-240.

Harrell, G. D., \& Mcconocha, D. M. (1992). Personal factors related to consumer product disposal tendencies. The Journal of Consumer Affairs, 26(2), 397-417. doi:10.1111/j.1745-6606.1992.tb00034.x

Hawkins, D. L., Best, R. J., \& Coney, K. A. (1989). Consumer behavior (4th ed.). MA: Homewood. IL: Irwin, Inc.

Hirschman, E. C., \& Holbrook, M. B. (1982). Hedonic consumption: Emerging concepts, methods, and propositions. Journal of Marketing, 46(3), 92-101.

Hwang, J. P., Tsai, S. J., Yang, C. H., Liu, K. M., Lirng, J. F. (1998). Hoarding behavior in dementia. A preliminary report. The American Journal of Geriatric Psychiatry, 6(4), 285-289.

Hyeon, H. M. (2014). The relations between hoarding, obsessive belief, indecisiveness and psychological well-being. Unpublished master's thesis, Catholic University, Seoul.

Howell, R. D. (1979). A multivariate examination of a patronage model: The impact of values and life style on shopping orientation. Unpublished doctoral dissertation, University of Arkansas, Fayetteville.

Jacoby, J. (1976). Consumer research: Telling it like it is. In B. B. Anderson (Ed.), Advances in Consumer Research, 3, 1-11.

Jacoby, J., Berning, C. K., \& Dietvorst, T. F. (1977). What about disposition. Journal of Marketing, 41(2), 22-28.

Jeon, J. O., \& Lee, E. K. (2013). Psychology of the people who can't throw away: Psychological mechanisms of compulsive hoarding behavior. Korea Marketing Review, 28(6), 109-136.

Ji, H. K. (2013). The influences of shopping orientation and impulse buying orientation on internet shopping addiction to fashion products. Journal of the Korean Fashion \& Costume Design Association, 15(2), 27-41.

Ju, K. W., \& Lee, E. J. (2015). The effect of shopping orientation, fashion innovativeness and perceived mobile benefits on mobile clothing purchase. Journal of the Korean Society of Fashion Design, 15(2), 147-164.

Jung, J. W. (1994). A study on the patterns of consumer disposition behavior and influential variables - Focusing on durable goods -. Unpublished master's thesis, Dong-Kuk University, Seoul.

Kang, E. M. (1999). The effects of related variables on the impulse buying behavior of apparel. Unpublished master's thesis, Dong-A University, Busan.

Kang, L. J. (1989). A study on the consumption patterns and life styles of homemakers of Seoul. Unpublished doctoral dissertation, DongKuk University, Seoul.

Kim, H. J., Chae, J. M., \& Oh, K. W. (2009). A study of shopping orientation and dissatisfactions of adolescence who are using internet malls. Journal of Korean Home Economics Education Association, 21(3), 65-81.

Kim, J. Y., \& Ha, K. S. (2011). Analysis of factors that affect the preference for imported clothing and imported copy clothing products by the tendency of consumer's clothing shopping. Journal of Consumption Culture, 14(2), 45-68.

Kim, S. H., \& Rhee, E. Y. (2004). A documentary study to determine the concept of clothing shopping orientation. Journal of the Korean Society of Clothing and Textiles, 28(6), 830-841.

Kim, S. H., \& Rhee, E. Y. (2000). Sales promotion response and shopping orientation of apparel consumers. Journal of Distribution Research, 5(1), 33-46.

Kim, S. W., \& Cho, H. S. (2000). A study on clothing recycling disposition behavior - Focusing on the unmarried women workers -. Journal of Korean Home Management Association, 18(2), 15-27.

Kim, S. Y., \& Rhee, E. Y. (1994). A study on clothing shopping orientations of consumers. Journal of the Korean Society of Clothing and Textiles, 18(3), 429-439.

Kong, J. H. (2012). Ethical consumption and clothing consumption behavior. Unpublished master's thesis, Chungnam National University, Daejeon.

Kwon, H. J. (2014). The effect of boredom on clothing disposal behavior. Unpublished master's thesis, Seoul National University, Seoul.

Lee, H. J., \& Ku, Y. S. (2011). The effect of duty free shop consumers' store benefits sought and fashion merchandise shopping orientation on store satisfaction. Fashion \& Textile Research Journal, 13(4), 572-581.

Lee, J. S., \& Choi, J. W. (2002). A study on the comparison of housewife's clothing management behaviors in rural \& urban community. Journal of the Korean Society of Clothing and Textiles, 26(1), 95-103.

Lee, J. Y., \& Hwang, J. S. (2015). Purchase intention and risk perception in overseas direct purchase according to shopping orientation. Journal of Korea Design Forum, 46, 205-218.

Lee, M. S. (2010). The effects of clothing shopping orientation on 
women consumers' clothing purchasing behaviors - Focused on a comparative analysis by age variable -. The Research Journal of the Costume Culture, 18(6), 1138-1152.

Leonard, H. L., Swedo, S. E., \& Rapoport, J. L. (1991). Diagnosis and treatment of obsessive-compulsive disorder in children and adolescents. In M. T. Pato \& J. Zohar (Eds.), Current treatments of obsessive-compulsive disorder (pp. 98-99). Washington, DC: American Psychiatric Press.

McAfee, A., Dessain, V., \& Sjoeman, A. (2004). Zara: IT for fast fashion. Cambridge, Boston, MA: Harvard Business Review Publishing.

Morgan, L. R. \& Birtwistle, G. (2009). An investigation of young fashion consumers' disposal habits. International Journal of Consumer Studies, 33(2), 190-198. doi:10.1111/j.1470-6431.2009.00756.x

Moye, L. N. \& Kincade, D. H. (2003). Shopping orientation segments: Exploring differences in store patronage and attitudes toward retail store environments among female apparel consumers. International Journal of Consumer Studies, 27(1), 58-71. doi:10.1046/j.14706431.2003.00260.x

Mueller, A., Mueller, U., Albert, P., Mertens, C., Silbermann, A., Mitchell, J. E., \& De Zwaan, M. (2007). Hoarding in a compulsive buying sample. Behaviour Research and Therapy, 45(11), 27542763. doi:10.1016/j.brat.2007.07.012

Nicosia, F. M., \& Mayer, R. N. (1976). Toward a sociology of consumption. Journal of Consumer Research, 3(2), 65-75. doi:10.1086/ 208653

Nunnally, J. C. (1978). Psychometric theory ( $2^{\text {nd }}$ ed.). New York, NY: McGraw-Hill.

Park, E. J., \& Kim, J. E. (2008). Relationships among shopping orientation, shopping-mall characteristics, consumer satisfaction, and loyalty in online market of cosmetics. The Research Journal of the Costume Culture, 16(4), 696-708.

Park, H. J., \& Na, Y. J. (2003). Sensation seeking tendency and shopping orientation affect on preferred fashion style of female college students. Fashion \& Textiles Research Journal, 5(5), 495502.

Pertusa, A., Frost, R. O., Fullana, M. A., Samuels, J., Steketee, G., Tolin, D., Saxena, S., Leckman, J. F., MataixCols, D. (2010). Refining the diagnostic boundaries of compulsive hoarding: A critical review. Clinical Psychology Review, 30(4), 371-386. doi:10.1016/j.cpr.2010.01.007

Salzman, L. (1973). The obsessive personality: Origins, dynamics and therapy. New York, NY: Jason Aronson.

Shim, S. Y., \& Kotsiopulos, A. (1993). A typology of apparel shopping orientation segments among female consumers. Clothing and Textiles Research Journal, 12(1), 73-85. doi:10.1177/0887302X9301200110

Soh, M. A., \& Park, K. H. (2001). A study on clothing behavior of women with and without an experience of imported clothes purchase - Focusing on shopping orientation and buying behavior -. Family and Environment Research, 39(6), 79-92.

Steketee, G., \& Frost, R. (2003). Compulsive hoarding: Current status of the research. Clinical Psychology Review, 23(7), 905-927. doi:10.1016/j.cpr.2003.08.002

Teddlie, C., \& Yu, F. (2007). Mixed methods sampling: A typology with examples. Journal of Mixed Methods Research, 1(1), 77-100. doi: $10.1177 / 2345678906292430$

VeVerka, M. J. (1974). Inactive clothing of selected families. Ames: Iowa State University.

Winakor, G. (1969). The process of clothing consumption. Journal of Home Economics, 61(8), 629-634.

Woodward, S. (2007). Why women wear what they wear?. Oxford: Berg.

(Received 16 August 2016; 1st Revised 27 September 2016; 2nd Revised 15 November 2016; Accepted 3 December 2016) 